\title{
Municipal solid wastes and mineral fertilizer as an eggplant transplant medium
}

\author{
A. Chrysargyris ${ }^{1}$, N. Tzortzakis ${ }^{2 *}$ \\ ${ }^{1}$ Department of Biology, University of Crete P.O. Box 2208, Heraklion, 71004, Crete, Greece \\ ${ }^{2}$ Department of Biological Greenhouse Crops and Floriculture, Technological Educational Institute of Crete, \\ Heraklion, 71004, Greece. \\ *Corresponding author: nikolaos.tzortzakis@cut.ac.cy
}

\begin{abstract}
The fertigation and/or municipal solid waste compost (MSWC) studied in eggplant seedlings. MSWC extracts (between $10^{-1}$ and $10^{-2}$ ) accelerated seedling germination. Under nursery conditions, six substrates prepared from commercial peat and MSWC and were further assessed in conjunction with the nutrient application as basic fertilizer (BF) or hydro fertilizer (HF). The addition of MSWC into the substrate inhibited seed emergence and mean germination time, while fertigation accelerated seed emergence in $15 \%$ MSWC. Addition of $60 \%$ MSWC reduced seedling height, leaf number and fresh weight. BF increased fresh weight in seedlings grown in $15 \%$ MSWC. Leaf Chlorophyll b content decreased but total carotenoids increased by adding MSWC into the substrate. The K content decreased, Na content increased while P content did not differ with MSWC addition. Fertigation benefits seedlings nutritive status. Low content (15-30\%) of MSWC may act as alternative substitute of peat with more positive effects observed if minerals provided through BF rather than HF.
\end{abstract}

Keywords: Compost, municipal solid waste, peat, growth, eggplant, seed emergence

\section{Introduction}

In Southern Europe, the use of peat as the main substrate component for production of seedlings in containers is widely expanded. However, peat is imported from Northern and Central Europe and recently has become more expensive as well as its properties more variable. The need to recycle wastes and increasing environmental pressures against peat extraction leads to an increasing interest in the feasibility of substituting peat by organic wastes and by-products. It is important to look for good quality and locally available low cost substitutes for peat. Several media as potential alternatives have been identified (Abad et al., 2001), and composts derived by different organic materials have proved to be promising (Sanchez-Monedero et al., 2004; Adriano et al., 2012), attracting researchers interest. The 
use of compost can be an important tool to control soil nutrition status (Adriano et al., 2012; Taheri et al., 2012) and soil-borne pathogens (Verma and Marschner, 2013; Zaccardelli et al., 2013). Certain groups of microorganisms (bacteria and fungi) present in compost produce metabolites, such as siderophores and antibiotics, with specific suppressive activity against soil-borne pathogens: among these compost bacteria, species of Pseudomonas and Bacillus are very important (Zaccardelli et al., 2013). However, the use of compost as a substrate component may cause some problems as a consequence of its high salt content (Castillo et al., 2004; Katayama et al., 2012), unsuitable physical properties and variable composition and quality (Hicklenton et al., 2001). Composts have to determine the correct amounts to use to improve plant growth (Ribeiro et al., 2007; Do and Scherer, 2013). Castillo et al. (2004) reported that mixtures of compost with perlite may be used as substrates without the need for additional mineral fertilizer, occasionally.

Municipal solid waste compost (MSWC) as an organic soil additive when applied in field trials, suggested that it can be used in agricultural production, improving soil physicochemical properties, increasing water retention as well as supply with considerable amount of essential nutrients (McConnell et al., 1993; Carbonell et al., 2011; Giannakis et al., 2011; Tzortzakis et al., 2012a). Municipal solid waste as organic material, is approximately $60-90 \%$ biodegradable and might be used as a bulking material to absorb excess water, and supply a useful raw product for the horticulture industry (Mami and Peyvast, 2010). Herrera et al. (2008) reported that urban waste compost can be used for tomato (Solanum lycopersicum L.) transplant production. Cucumber (Cucumis sativus L.) is a crop that can also be started as transplants (Mami and Peyvast, 2010). However, little information is available regarding the use of MSWC as a peat alternative for nursery production of horticultural crops (Tzortzakis et al., 2012b; Chrysargyris et al., 2013; Do and Scherer, 2013). Indeed, most studies have focused on ornamental potted plants, woody shrubs and trees (Fitzpatrick et al., 1998). Additionally, each particular compost has to find the best amounts for particular plant growth as there is no one standard growing medium recommended for all container crops under all growing conditions.

A previous study showed that the growth and development of nursery-produced tomato seedlings using a peat+MSWC mixture was similar to that obtained with the standard peat mixture (Castillo et al., 2004), while melon, marigold and basil seedling production benefited with the adding of MSWC into substrate medium (Tzortzakis et al., 2012b; Chrysargyris et al., 2013). The present study sought to evaluate the effect of varying the proportion of MSWC mixed with conventional peat substrates, as a growth medium in the nursery production of eggplant seedlings.

\section{Material and Methods}

\subsection{Seed and municipal solid waste compost source}

Seeds of eggplant (Solanum melongena L. cv Lagada) were purchased from Agrimore (Agrimore SA, Thessaloniki, Greece) company. Municipal solid waste compost punctuated by Inter-Municipal Enterprise for the Management of Solid Wastes, based in Chania, Greece. The compost used was made from the organic fraction of selectively-collected urban waste and was arranged in piles of $5 \mathrm{~m}$ wide of $2.5 \mathrm{~m}$ high of $45 \mathrm{~m}$ long, which were regularly turned and watered over a 5-6 months period to ensure appropriate composting conditions (turned windrow system). This material 
was then passed through a densimetric table and a 15 $\mathrm{mm}$ trommel screen to remove the largest particles. The composting procedure lasted for 5-6 months. The $60 \%$ of compost consisted of particles less than $4 \mathrm{~mm}$ size. Several physicochemical and nutritional parameters of compost material were measured. Organic matter content was determined after samples were ashed at $550^{\circ} \mathrm{C}$ for eight hours and the organic $\mathrm{C}$ was calculated. The electrical conductivity (EC) and $\mathrm{pH}$ determined according to 1:1 dilution method, employing a portable pH/EC-meter (HI $98130 \mathrm{HR}$, Hanna Instruments, USA). After a hydrochloric digestion of the sample ash, nutrients analysis for $\mathrm{K}$ and Na (photometric; JENWAY, PEP-7 Jenway, Dunmow, UK), P (spectrophotometric; Pye Unicam Hitachi U-1100, Tokyo, Japan) was determined while total $\mathrm{N}$ determined through Kjeldahl method.

\subsection{MSWC extracts and germination studies in vitro}

A 2-L capacity plastic container was filled with MSWC:water (1:1.5) and was shaking for $24 \mathrm{~h}$. The $\mathrm{EC}$ and $\mathrm{pH}$ of MSWC extract were evaluated. The MSWC extract was diluted in the ratios: 1:0, 1:10, 1:100, 1:1000, 1:10000, 1:100000 (MSWC:water at $10^{-0}$ up to $10^{-6}$ dilutions). For germination tests, air-dried eggplant seeds were placed in Petri dishes with filter paper (four replicates/treatment, 25 seeds/replicate) in a completely randomized design under laboratory conditions (average temperatures: $24.1 \pm 2.3^{\circ} \mathrm{C} \max , 21.5 \pm 2.8^{\circ} \mathrm{C} \mathrm{min}$ ) and monitored daily. Filter papers were moistened daily using aliquots $(\sim 5 \mathrm{~mL})$ of diluted MSWC extract for the six treatments. Plates moisturised with $\mathrm{dH}_{2} \mathrm{O}$ were controls. Seeds were considered germinated upon radicle emergence. Mean shoot and root length was evaluated on the eighth day.

\subsection{Germination and plant growth studies in nursery tests}

Under nursery condition, a mix of commercial compost peat (Professional peat, Gebr. Brill Substrate $\mathrm{GmbH}$ \& Co.KG, Georgsdorf, Germany), perlite (Perloflor, Protectivo EPE, Athens, Greece) and MSWC were used in different ratio to create six treatments which were ( $\% \mathrm{v} / \mathrm{v}): 1)$ peat:MSWC (100:0) as control, 2) peat:MSWC (85:15), 3) peat:MSWC (70:30), 4) peat:MSWC (55:45), 5) peat:MSWC (40:60) and 6) peat:MSWC (0:100). In order to examine the impact of fertigation itself in seedlings development, a low MSWC (15\%) and a high (45\%) MSWC content evaluated in combination with or without fertigation. Thus, additionally to the previous mixtures, four treatments created 7) peat:MSWC (85:15) with basic fertilizer (BF), 8) peat:MSWC (55:45) with BF, 9) peat:MSWC (85:15) with weekly hydro fertilizer (HF), 10) peat:MSWC (55:45) with HF. BF applied (1.5 $\left.\mathrm{kg} \mathrm{m}^{-3}\right)$ once before sowing and HF (20-20-20) applied on a weekly basis. In each substrate medium was added $10 \%$ of perlite.

Seeds of eggplant were sown (0.5 cm depth; $1.0-1.5$ $\mathrm{cm}$ between seeds in plastic seedling trays ( 5 seeds per well; 4 wells per replication; 5 replications per treatment, $40 \mathrm{~cm}^{3}$ well capacity) on top of the surface of the each medium. The experiment was carried out in a completely randomized design in an unheated glasshouse (temperature: $25.7 \pm 6.8^{\circ} \mathrm{C} \max , 15.1 \pm 5.1^{\circ} \mathrm{C}$ min; RH (\%): 93.5 $\pm 1.9 \max , 74.8 \pm 4.1 \mathrm{~min})$ with alternate-day watering by mist system (initially with $1 \mathrm{~min} / 2 \mathrm{~h}$ and then up to $1 \mathrm{~min} / 5 \mathrm{~h}$ ).

Over the seedling growth-period in the nursery, no fertilizer was applied; seedling nutritional requirements were thus met entirely by the substrates. Daily observations recorded for seed germination (seeds recorded as emerged when the hypocotyls appeared above substrate medium surface). After 
19-days seedlings were thinned to single plant, maintaining 4-5 cm distance among seedlings. Mean germination time (MGT) was calculated as follows, according to Labouriau (1983):

$$
\mathrm{t}=\frac{\sum n i \cdot t i}{\sum n} \text { (days) }
$$

where: $t=$ mean germination time, $t i=$ given time interval, $n i=$ number of germinated seeds during a given time interval, $n=$ total number of germinated seeds.

After 45 days, seedling growth was assessed by harvesting six individuals/treatment. Seedlings were harvested above substrate, the leaf number and height (cm) per seedling, measured from substrate surface, stem diameter $(\mathrm{mm})$ measured below the cotyledon node, upper fresh weight ( $\mathrm{g}$ ), total dry matter content (\%), content ( $\mu \mathrm{g} / \mathrm{g}$ fresh weight) of chlorophyll a (Chla), chlorophyll b (Chlb) and total carotenoids (Car) determined according to Porra (2002). Leaf fluoresces determined (chlorophyll fluoremeter, optisciences OS-30p, UK) and leaf photosynthetic rate $(p n)$, the stomatal conductance $(g s)$ and the internal leaf concentration of $\mathrm{CO}_{2}(\mathrm{Ci})$ measured using a portable infra-red gas analyser (model Li-6200, LiCor, Inc., Lincoln, Nebr.). Measurements were carried out between 9:00-11:10AM, the leaf temperature within the chamber was $(28 \pm 2)^{\circ} \mathrm{C}$, photosynthetic photon flux density of $1300 \mu \mathrm{mol} / \mathrm{m}^{2} / \mathrm{s}$ at the ambient $\mathrm{CO}_{2}$ concentration. The Li 6200 was equipped with a leaf chamber with constant area inserts $\left(6.0 \mathrm{~cm}^{2}\right)$. All gas-exchange measurements started $3 \mathrm{~h}$ after the onset of the photoperiod and were replicated in nine plants of each treatment and on two fully expanded, healthy, sun-exposed leaves per plant.

Leafelementalanalysis forpotassium-K, phosphorus-P, sodium-Na and nitrogen-N was determined at the end of the experiments. After a hydrochloric digestion of the plant sample ash, nutrients analysis for $\mathrm{K}$ and $\mathrm{Na}$ (photometric; JENWAY, PEP-7 Jenway, Dunmow, UK), P (spectrophotometric; Pye Unicam Hitachi U-1100, Tokyo, Japan) was determined while total N determined through Kjeldahl method.

\subsection{Statistical analysis}

The experiments were carried out twice. Percentage data were log-transformed before analysis. Data were tested for normality, and then subjected to analysis of variance (ANOVA). Significant differences between mean values were determined using Duncan's Multiple Range test following one-way ANOVA. Statistical analyses were performed using SPSS (SPSS Inc., Chicago, Ill.).

\section{Results and Discussion}

\subsection{Compost properties}

The main physicochemical characteristics of compost (dry weight: dwt) were $\mathrm{pH}: 7.7$; EC: $17.9 \mathrm{dS} \mathrm{m}^{-1}$; ashes: $50.1 \% \mathrm{dwt}$; organic matter: $49.9 \% \mathrm{dwt}$; organic Carbon: $27.2 \%$ dwt; N: $1.9 \%$ dwt; ratio C/N: 14.3 ; P: $164 \mu \mathrm{g} \mathrm{g}^{-1}$; K: $727 \mu \mathrm{g} \mathrm{g}^{-1}$; Na: $403 \mu \mathrm{g} \mathrm{g}^{-1}$, under low limits for heavy metal content. $\mathrm{The} \mathrm{C} / \mathrm{N}$ ratio is widely used as an indicator of the maturity and stability of organic matter. This low value of $\mathrm{C} / \mathrm{N}$ ratio in MSWC suggested that composts were stable and mature as indicated by Davidson et al. (1994) who reported that composts with a $\mathrm{C} / \mathrm{N}$ ratio of less than 20 are ideal for nursery plant production. Ratios above 30 may be toxic, causing plant death (Zucconi et al., 1981).

\subsection{Seed germination and emergence time in vitro}

The first germination was observed after five days while the final germination was obtained before nine days. MSWC extract at $10^{-1}-10^{-2}$ concentrations 
increased seed germination comparing with the control treatment (water) while no differences observed in more diluted extracts (Figure 1A). However, when pure $\left(10^{-0}\right.$ concentration) extract used, seed germination was complete inhibited and this may be attributed to the high $\mathrm{EC}$ and $\mathrm{pH}$ values of MSWC extract (EC: $11.21 \mathrm{dS} \mathrm{m}^{-1}$; $\mathrm{pH}$ : 6.87). In previous studies, it was reported that there was no inhibition of germination in case of cucumber seeds in relation to the control treatment when MSWC: water extracts used (Pal and Bhattacharyya, 2003). Recent finding revealed that MSWC may enhance melon seed germination at $10^{-2}-10^{-6}$ extract concentrations (Chrysargyris et al., 2013), which is in accordance with the present study, and highlights the importance of the developed seed priming techniques (Ashraf and Foolad, 2005).The MSWC extract increased shoot length at concentrations of $10^{-1}$ to $10^{-4}$ and root radicle length at concentrations of $10^{-3}-10^{-4}$ of germinated seeds comparing with the water treatment, while pure MSWC extract failed germination (Figure 1B). Similar findings observed in previous studies when olive-mill wastes extracts used for seed priming procedure in lettuce and radish (Kelepesi and Tzortzakis, 2009). Indeed, root length and shoot length suppressed when cucumber seeds treated with 1:7.5 MSWC: water extracts (Pal and Bhattacharyya, 2003). The stimulatory effects due to MSWC extract on seed germination may help early seed germination, providing a higher competitive ability (Zhang and Maun, 1990) and reducing mortality.

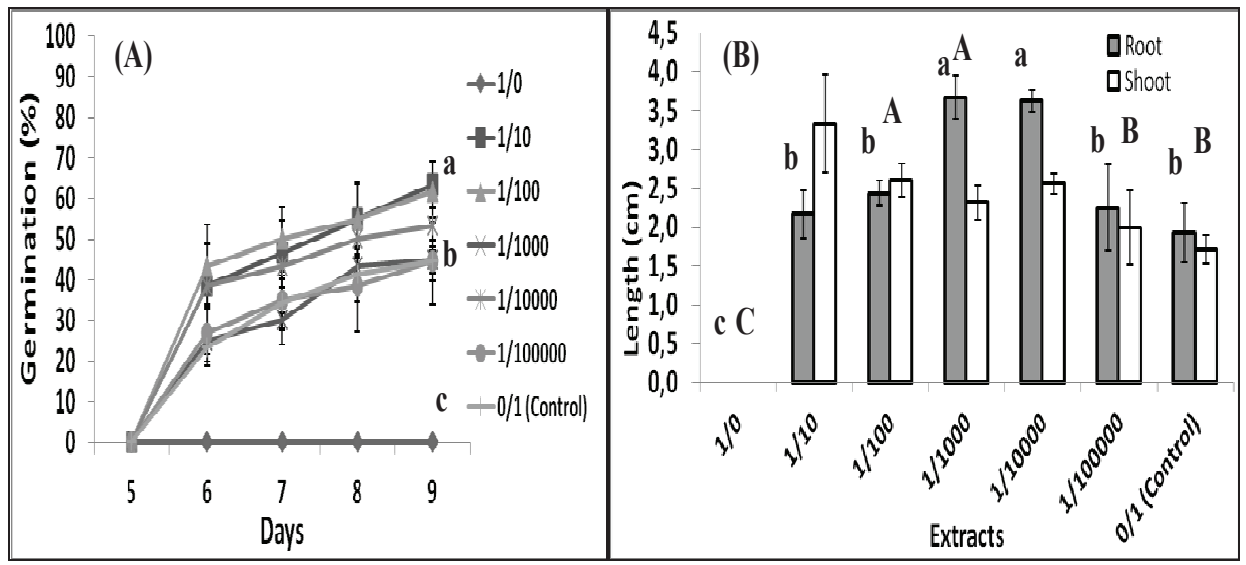

Figure 1. Effects of municipal solid waste compost extracts at concentrations $\left(10^{\circ}-10^{-6}\right)$ on $(A)$ cumulative seed germination and (B) on shoot and root length of eggplant in vitro. Values represent mean $( \pm \mathrm{SE})$ of measurements made on four Petri dishes $(25$ seeds and five radicles/dish) per treatment. Mean values followed by the same letter do not differ significantly at $p=0.05$ according to Duncan's MRT.

\subsection{Seed germination and emergence time in vivo}

The first germination observed after six days of sowing while the first true-leaf emerged after eleven days. The ratios of peat and MSWC used into the mixtures as well as the fertigation affected seed germination/emergence (Figures 2A, B). Eggplant treated with the 85:15 peat:
MSWC ratios decreased (up to 24\%) seed emergence comparing with the control (100\% peat) which contrast previous studies in basil seedlings (Tzortzakis et al., $2012 \mathrm{~b}$ ) and this is probably due to the different plant species and/or plant vigour. Moreover, increased (> $30 \%)$ MSWC content into the substrate resulted in substantial (up to $76 \%$ ) inhibition of seed emergence 
(see Figure 2A), as this was evidence in previous study with melon seedling production with MSWC in different ratio (Chrysargyris et al., 2013). Examining the impact of fertigation, seed emergence increased (up to $13 \%$ ) in the $85: 15$ peat:MSWC mixture, either with basic- or hydro-fertilization, comparing with the relevant control treatment (85:15 peat:MSWC, see Figure 2B). When higher (45\%) MSWC content used, the fertigation did not improve seed emergence, adequately, and this is probably due to the high EC value as a result of the higher MSWC content and/or fertigation add.
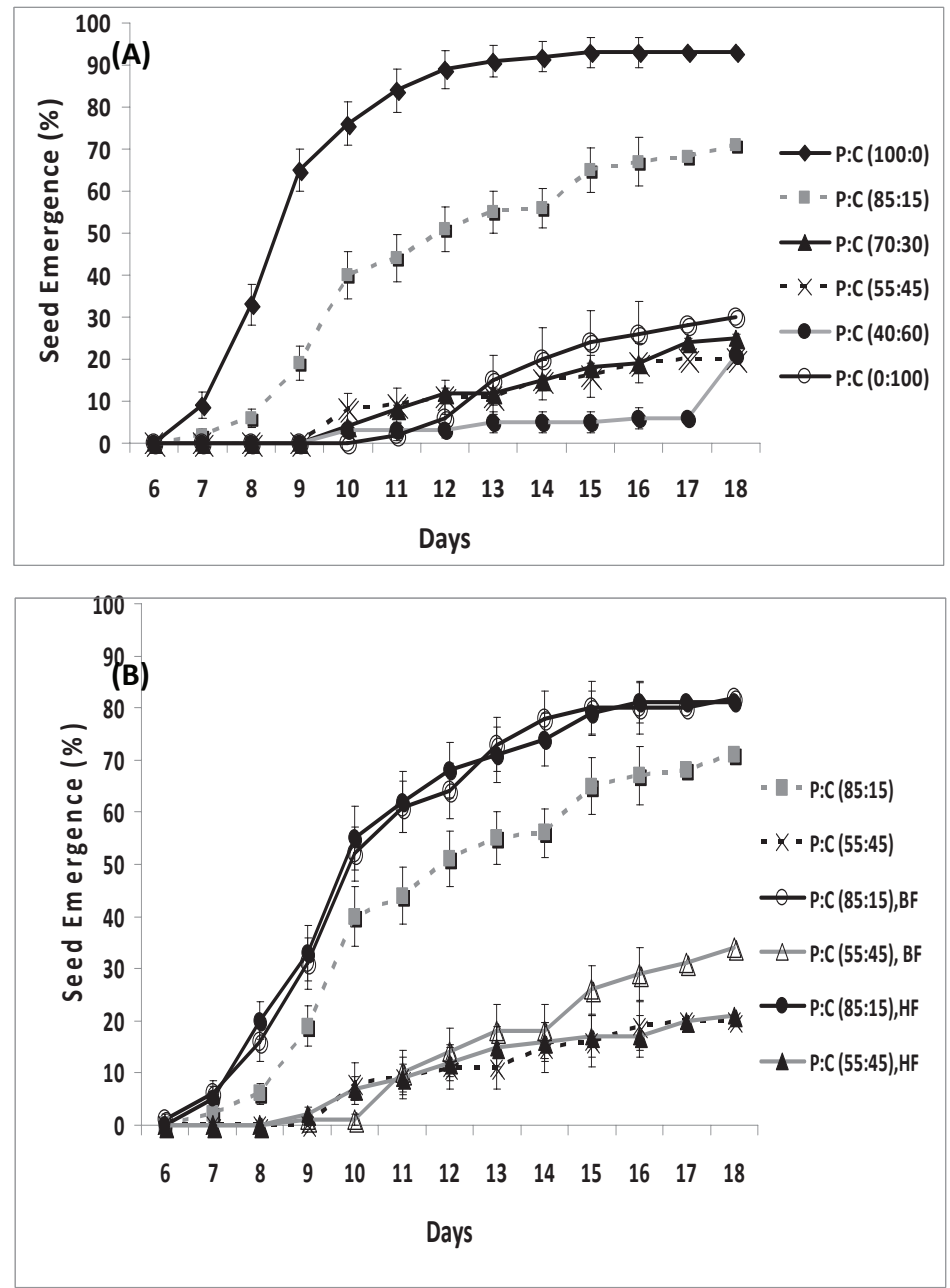

Figure 2. Influence of (A) substrate medium (commercial peat-P, municipal solid waste compost-C) and/or (B) fertigation (basic fertilization-BF, hydro fertilization-HF) on cumulative seedling emergence of eggplant seeds germinated in greenhouse nursery. Values represent mean $( \pm \mathrm{SE}$ ) of measurements made on 5 independent replication ( 4 wells per replication; 5 seeds per well) per treatment. Mean values followed by the same letter do not differ significantly at $\mathrm{P}=0.05$ according to Duncan's MRT. 
The different mixtures derived by peat and MSWC ratio, affected seed MGT while the application of fertilizer did not affect the seed MGT (Figure 3A,B). Thus, increased MSWC content into the substrate resulted in MGT increment (up to 6 days delay) which is in accordance with previous studies employing MSWC in melon seeds emergence (Chrysargyris et al., 2013). The adding of fertilizers into the substrates with low MSWC content benefits seed germination/emergence, possible due to the fact that fertilizers provided nutritional value while MSWC provided additional nutrition as organic material and/or improved substrate medium properties. The stimulation of several presowing treatments (hydropriming; halopriming; osmopriming, thermopriming; solid matrix priming and biopriming as reported by Ashraf and Foolad 2005) of seed comparing with untreated seeds might be due to altered physiology of embryos and activation of enzymes, so that developmental processes occur more rapidly after sowing (Kattimani et al., 1999) and this is possible with the seed germination under MSWCfertigation enrichment.

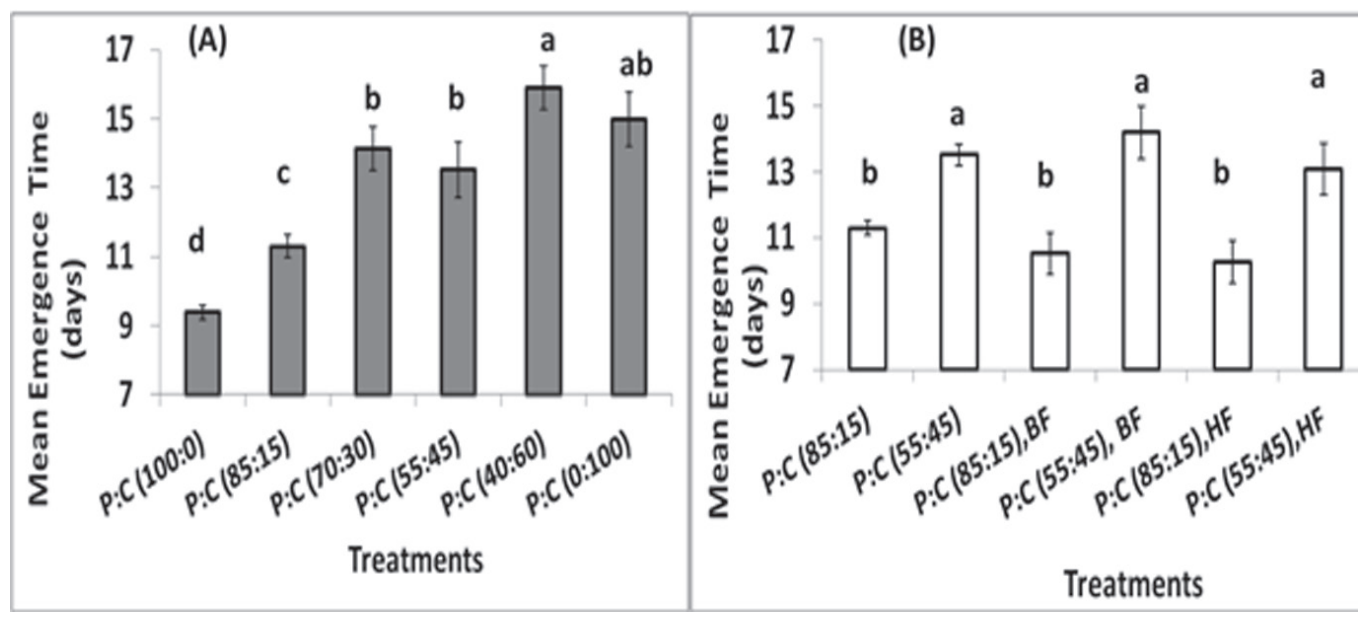

Figure 3. Mean emergence time for eggplant in (A) different substrate medium (commercial peat-P, municipal solid waste compost-C) and/or (B) fertigation (basic fertilization-BF, hydro fertilization-HF) under nursery condition. Values represent mean $( \pm \mathrm{SE})$ of measurements made on 5 replication (4 wells per replication; 5 seeds per well) per treatment. Mean values followed by the same letter do not differ significantly at $p=0.05$ according to Duncan's MRT.

Although there is no single, ideal growth medium for nursery-produced horticultural crops (Bugbee, 1996), most greenhouse-grown species display better growth at slight acid $\mathrm{pH}$ values (5.2-7.0); peat mixtures approached these values but MSWC did not. Thus, further exploitation is needed, in order to indentify the type of fertilizer used into the mixtures as its well known that may increase (i.e. potassium nitrate) or decrease (i.e. ammonium nitrate) the $\mathrm{pH}$ of a medium. Like $\mathrm{pH}$ levels, the highest initial substrate EC values were recorded for mixtures containing MSWC. Ribeiro and e Santos (1997) reported that substrates with high EC values reduce water retention, negatively affecting the imbibing process and may delay seed emergence rates, which actually reflected the findings of the present study. 


\subsection{Seedling growth in vivo}

Analyses of variance showed that the addition of $60 \%$ MSWC in commercial peat significantly reduced (up to $44 \%$ ) for both seedling height and stem diameter (Table 1). When higher content, as pure (100\%) MSWC, used the reduction was up to $29 \%$ for seedling height, up to $26 \%$ for leaf number, up to $55 \%$ for fresh weight and up to $15 \%$ for dry matter content comparing with the control treatment ( $100 \%$ peat) (see Table 1). This findings are in agreement with previous studies in cucumber and melon seedlings (Mami and Peyvast, 2010; Chrysargyris et al., 2013) whereas MSWC increased EC as well as N immobilization and/or decreased $\mathrm{N}$ mineralization that were responsible for inhibited growth by constraining $\mathrm{N}$ availability in tomato and lettuce crops (Giannakis et al.,
2011). No differences observed in leaf number produced and stem diameter regarding the different fertilizer application in low and high MSWC content substrates. Basic fertigation increased fresh weight in seedlings grown in $15 \%$ MSWC substrate but reverse impacts marked in 45\% MSWC substrate treatment. Interesting, the application of fertilizers, either as basic- or hydrofertilizer reduced the dry matter content (between 18 to $25 \%$ ). Thus, seedlings grown in the MSWC mixtures in high content displayed worse quality and suitability for transplanting, possible due to increased EC and/or alternated medium physicochemical properties. Seedling resistance to transplant stress is directly related to dry matter content, which improves seedling establishment in the soil or growth substrate (Pimpini and Gianquinto, 1991).

Table 1. Impact of fertigation (basic fertilization-BF, hydro fertilization-HF) and substrate medium (commercial peat-P, municipal solid waste compost-C) on seedling height ( $\mathrm{cm} /$ plant), number of leaf produced, stem diameter (mm), fresh weight (g/plant), dry matter content (\%) on eggplant seedlings grown in the nursery.

\begin{tabular}{|c|c|c|c|c|c|}
\hline & Height & Leaf No & Stem diameter & Fresh weight & Dry matter \\
\hline P:C (100:0) & $10.76^{\mathrm{a}, \mathrm{Y}}$ & $3.83^{\mathrm{a}}$ & $2.42^{\mathrm{a}}$ & $1.95^{\mathrm{a}}$ & $8.63^{\mathrm{a}}$ \\
\hline $\mathrm{P}: \mathrm{C}(85: 15)$ & $9.78^{\mathrm{a}, \mathrm{A}}$ & $3.51^{\mathrm{a}, \mathrm{A}}$ & $2.17^{\mathrm{a}, \mathrm{A}}$ & $1.56^{\mathrm{a}, \mathrm{B}}$ & $9.03^{\mathrm{a}, \mathrm{A}}$ \\
\hline $\mathrm{P}: \mathrm{C}(70: 30)$ & $9.00^{\mathrm{a}}$ & $3.17^{\mathrm{a}}$ & $1.92^{\mathrm{a}}$ & $1.45^{\mathrm{a}}$ & $9.01^{\mathrm{a}}$ \\
\hline $\mathrm{P}: \mathrm{C}(55: 45)$ & $10.01^{\mathrm{a}, \mathrm{A}}$ & $3.52^{\mathrm{a}, \mathrm{A}}$ & $2.14^{\mathrm{a}, \mathrm{A}}$ & $1.63^{\mathrm{a}, \mathrm{B}}$ & $10.18^{\mathrm{a}, \mathrm{A}}$ \\
\hline $\mathrm{P}: \mathrm{C}(40: 60)$ & $6.05^{\mathrm{b}}$ & $4.01^{\mathrm{a}}$ & $1.36^{\mathrm{b}}$ & $1.78^{\mathrm{a}}$ & $8.31^{\mathrm{a}}$ \\
\hline $\mathrm{P}: \mathrm{C}(0: 100)$ & $7.61^{\mathrm{b}}$ & $2.83^{\mathrm{b}}$ & $1.83^{\mathrm{a}}$ & $0.86^{\mathrm{b}}$ & $7.32^{\mathrm{b}}$ \\
\hline $\mathrm{P}: \mathrm{C}(85: 15), \mathrm{BF}$ & $10.91^{\mathrm{A}}$ & $3.83^{\mathrm{A}}$ & $2.07^{\mathrm{A}}$ & $2.51^{\mathrm{A}}$ & $7.61^{\mathrm{B}}$ \\
\hline $\mathrm{P}: \mathrm{C}(55: 45), \mathrm{BF}$ & $8.65^{\mathrm{B}}$ & $3.84^{\mathrm{A}}$ & $1.94^{\mathrm{A}}$ & $1.28^{\mathrm{C}}$ & $7.64^{\mathrm{B}}$ \\
\hline $\mathrm{P}: \mathrm{C}(85: 15), \mathrm{HF}$ & $10.56^{\mathrm{A}}$ & $4.00^{\mathrm{A}}$ & $2.24^{\mathrm{A}}$ & $1.73^{\mathrm{B}}$ & $7.10^{\mathrm{B}}$ \\
\hline $\mathrm{P}: C(55: 45), H F$ & $9.35^{\mathrm{AB}}$ & $3.53^{\mathrm{A}}$ & $1.83^{\mathrm{A}}$ & $1.41^{\mathrm{B}}$ & $7.62^{\mathrm{B}}$ \\
\hline
\end{tabular}

${ }^{\mathrm{Y}}$ values $(n=6)$ in columns followed by the same small letter are not significantly different, $P<0.05$, regarding substrate medium and in columns followed by the same capital letter are not significantly different, $p<0.05$, regarding the fertigation impacts.

In case of different MSWC content, the addition of MSWC into the substrate decreased the leaf Chlb content of eggplant seedlings but increased total carotenoids while the Chla content increased in $45 \%$ of MSWC substrate (Table 2), which is actually the primary photosynthetic pigment and $\mathrm{Chlb}$ is the accessory pigment that collects the energy to pass on to Chla. This fluctuation might be one reason that no 
changes observed in leaf photosynthetic rate and leaf stomatal conductance among treatments. No differences observed in leaf fluoresces (averaged in $0.81 \mathrm{Fv} / \mathrm{Fm}$ ) as well as in the leaf internal $\mathrm{CO}_{2}$ concentration (averaged in $316.63 \mu \mathrm{mol} \mathrm{mol}{ }^{-1}$ ). Examining the impacts of fertigation in seedling growth, Chlb content increased with the HF application independently of the MSWC content into the substrate while the application of BF did not have any input. Fertigation (BF and HF) increased the seedling leaf photosynthetic rate with greater impacts in higher MSWC content. Leaf stomatal conductance differed among treatments without a specific trend. No major changes observed in leaf fluoresces (averaged in $0.81 \mathrm{Fv} / \mathrm{Fm}$ ), total carotenoids (averaged in $30.58 \mu \mathrm{g} / \mathrm{g}$ $\mathrm{fw})$ as well as in the leaf internal $\mathrm{CO}_{2}$ concentration (averaged in $289.14 \mu \mathrm{mol} \mathrm{mol}^{-1}$ ).

Table 2. Impact of fertigation (basic fertilization-BF, hydro fertilization-HF) and substrate medium (commercial peat-P, municipal solid waste compost-C) on leaf fluoresces (Fv/Fm), Chlorophyll a (Chla; $\left.\mu \mathrm{g} \mathrm{g}^{-1} \mathrm{fw}\right)$, Chlorophyll b (Chlb; $\mu \mathrm{g} \mathrm{g}{ }^{-1}$ fw), total carotenoids (Car; $\left.\mu \mathrm{g} \mathrm{g}^{-1} \mathrm{fw}\right)$, leaf photosynthetic rate $\left(\mathrm{P}_{\mathrm{n}}: \mu \mathrm{mol} \mathrm{m} \mathrm{m}^{-2} \mathrm{~s}^{-1}\right)$, leaf stomatal conductance $\left(\mathrm{g}_{\mathrm{s}}: \mu \mathrm{mol} \mathrm{m}^{-2} \mathrm{~s}^{-1}\right)$ and leaf

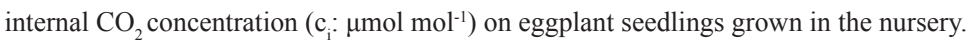

\begin{tabular}{|c|c|c|c|c|c|c|c|}
\hline & Fluoresces & Chla & Chlb & Car & $P_{n}$ & $\mathrm{~g}_{\mathrm{s}}$ & $\mathrm{c}_{\mathrm{i}}$ \\
\hline P:C (100:0) & $0.82^{a, Y}$ & $54.01^{b}$ & $38.27^{\mathrm{a}}$ & $26.25^{b}$ & $6.26^{\mathrm{a}}$ & $0.316^{\mathrm{a}}$ & $330.4^{a}$ \\
\hline$P: C(85: 15)$ & $0.80^{\mathrm{a}, \mathrm{A}}$ & $57.15^{\mathrm{ab}, \mathrm{AB}}$ & $15.16^{\mathrm{b}, \mathrm{B}}$ & $30.73^{\mathrm{a}, \mathrm{A}}$ & $5.71^{\mathrm{a}, \mathrm{C}}$ & $0.279^{a b, B}$ & $309.5^{\mathrm{a}, \mathrm{A}}$ \\
\hline P:C (70:30) & $0.82^{a}$ & $57.55^{\mathrm{ab}}$ & $20.14^{\mathrm{b}}$ & $32.01^{\mathrm{a}}$ & $7.37^{\mathrm{a}}$ & $0.224^{\mathrm{ab}}$ & $285.8^{a}$ \\
\hline$P: C(55: 45)$ & $0.82^{\mathrm{a}, \mathrm{A}}$ & $58.10^{\mathrm{a}, \mathrm{A}}$ & $16.47^{\mathrm{b}, \mathrm{B}}$ & $31.41^{\mathrm{a}, \mathrm{A}}$ & $5.67^{\mathrm{a}, \mathrm{C}}$ & $0.189^{b, C}$ & $306.4^{\mathrm{a}, \mathrm{A}}$ \\
\hline $\mathrm{P}: \mathrm{C}(40: 60)$ & $0.81^{a}$ & $58.05^{a b}$ & $16.37^{\mathrm{b}}$ & $32.77^{\mathrm{a}}$ & $4.92^{b}$ & $0.292^{\text {a }}$ & $345.9^{a}$ \\
\hline P:C (0:100) & $0.83^{a}$ & 57.37 ab & $19.53^{b}$ & $31.47^{\mathrm{a}}$ & $5.74^{\mathrm{ab}}$ & $0.269^{\mathrm{ab}}$ & $321.6^{\mathrm{a}}$ \\
\hline $\mathrm{P}: \mathrm{C}(85: 15), \mathrm{BF}$ & $0.81^{\mathrm{A}}$ & $56.80^{\mathrm{AB}}$ & $18.08^{\mathrm{B}}$ & $31.50^{\mathrm{A}}$ & $7.98^{\text {в }}$ & $0.164^{\mathrm{C}}$ & $281.1^{\mathrm{AB}}$ \\
\hline $\mathrm{P}: \mathrm{C}(55: 45), \mathrm{BF}$ & $0.83^{\mathrm{A}}$ & $57.47^{\mathrm{AB}}$ & $20.57^{\mathrm{B}}$ & $32.22^{\mathrm{A}}$ & $10.01^{\mathrm{A}}$ & $0.196^{\mathrm{C}}$ & $281.1^{\mathrm{AB}}$ \\
\hline P:C (85:15),HF & $0.82^{\mathrm{A}}$ & $55.59^{\mathrm{B}}$ & $38.06^{\mathrm{A}}$ & $29.53^{\mathrm{AB}}$ & $8.25^{\text {B }}$ & $0.110^{\mathrm{D}}$ & $242.1^{\text {B }}$ \\
\hline $\mathrm{P}: \mathrm{C}(55: 45), \mathrm{HF}$ & $0.82^{\mathrm{A}}$ & $54.59^{\text {в }}$ & $40.31^{\mathrm{A}}$ & $28.10^{\mathrm{B}}$ & $11.27^{\mathrm{A}}$ & $0.421^{\mathrm{A}}$ & $318.6^{\mathrm{A}}$ \\
\hline
\end{tabular}

${ }^{\mathrm{Y}}$ values $(n=6)$ in columns followed by the same small letter are not significantly different, $P<0.05$, regarding substrate medium and in columns followed by the same capital letter are not significantly different, $p<0.05$, regarding the fertigation impacts.

Leaf elemental content revealed $\mathrm{K}$ decrease (up to $41 \%$ ) with the addition of MSWC into the substrate while $\mathrm{Na}$ content increased (up to $73 \%$ ) in seedlings grown in $>45 \%$ MSWC (Table 3 ) being in agreement with melon seedling production with the same MSWC (Chrysargyris et al., 2013). Salt and osmotic stresses are responsible for both inhibition or delayed seed germination and seedling establishment (Almansouri et al., 2001). Under these stresses there is a decrease in water uptake during inhibitions and furthermore salt stress may cause excessive uptake of ions (Murillo-Amador et al., 2002). In addition, a
$\mathrm{pH}$ increase is usually observed in soils that accept MSW compost, which makes metals less mobile and less available (Hargreaves et al., 2008). MSW compost, on the other hand, can increase soluble salt content (electrical conductivity), which has been found to adversely affect seed and shoot growth (Farrell and Jones, 2009). As a matter of fact, the increased salt stress cause by the addition of MSWC, affected negatively several plant growth parameters, as presented on Table 1. However, N leaf content increased in seedlings grown in substrates with 15$30 \%$ MSWC. No differences (averaged in $0.011 \mathrm{mg}$ 
$\mathrm{g}^{-1} \mathrm{fw}$ ) observed in P content among seedlings grown in substrates with different MSWC content; due to the limited nutrient support for $\mathrm{P}$ by the MSWC add into the substrate. It is well know that compost lacks $\mathrm{P}$ and this nutrient is necessary to be added by alternative source such as fertilizers, while the $\mathrm{P}$ availability into the soil is also of great research interest (Taheri et al., 2012; Verma and Marschne, 2013).

Table 3. Impact of fertigation (basic fertilization-BF, hydro fertilization-HF) and substrate medium (commercial peat-P, municipal solid waste compost-C) on leaf elemental ( $\mathrm{N}, \mathrm{K}, \mathrm{P}, \mathrm{Na})$ concentration $(\mathrm{mg} / \mathrm{g}$ fresh weight) on eggplant seedlings grown in the nursery.

\begin{tabular}{|c|c|c|c|c|}
\hline & $\mathrm{N}$ & $\mathrm{K}$ & $\mathrm{P}$ & $\mathrm{Na}$ \\
\hline $\mathrm{P}: \mathrm{C}(100: 0)$ & $13.81^{\mathrm{b}, \mathrm{Z}}$ & $0.244^{\mathrm{a}}$ & $0.013^{\mathrm{a}}$ & $0.016^{\mathrm{c}}$ \\
\hline $\mathrm{P}: \mathrm{C}(85: 15)$ & $17.96^{\mathrm{a}, \mathrm{A}}$ & $0.181^{\mathrm{b}, \mathrm{B}}$ & $0.009^{\mathrm{a}, \mathrm{A}}$ & $0.017^{\mathrm{c}, \mathrm{B}}$ \\
\hline $\mathrm{P}: \mathrm{C}(70: 30)$ & $17.13^{\mathrm{a}}$ & $0.174^{\mathrm{b}}$ & $0.009^{\mathrm{a}}$ & $0.026^{\mathrm{c}}$ \\
\hline $\mathrm{P}: \mathrm{C}(55: 45)$ & $14.52^{\mathrm{ab}, \mathrm{A}}$ & $0.176^{\mathrm{b}, \mathrm{B}}$ & $0.010^{\mathrm{a}, \mathrm{A}}$ & $0.042^{\mathrm{b}, \mathrm{A}}$ \\
\hline $\mathrm{P}: \mathrm{C}(40: 60)$ & $14.29^{\mathrm{ab}}$ & $0.158^{\mathrm{b}}$ & $0.009^{\mathrm{a}}$ & $0.050^{\mathrm{ab}}$ \\
\hline $\mathrm{P}: \mathrm{C}(0: 100)$ & $14.11^{\mathrm{a}}$ & $0.143^{\mathrm{b}}$ & $0.010^{\mathrm{a}}$ & $0.059^{\mathrm{a}}$ \\
\hline $\mathrm{P}: \mathrm{C}(85: 15), \mathrm{BF}$ & $13.42^{\mathrm{B}}$ & $0.225^{\mathrm{A}}$ & $0.011^{\mathrm{A}}$ & $0.027^{\mathrm{B}}$ \\
\hline $\mathrm{P}: \mathrm{C}(55: 45), \mathrm{BF}$ & $17.65^{\mathrm{A}}$ & $0.113^{\mathrm{B}}$ & $0.010^{\mathrm{A}}$ & $0.036^{\mathrm{AB}}$ \\
\hline $\mathrm{P}: \mathrm{C}(85: 15), \mathrm{HF}$ & $15.55^{\mathrm{AB}}$ & $0.232^{\mathrm{A}}$ & $0.010^{\mathrm{A}}$ & $0.012^{\mathrm{C}}$ \\
\hline $\mathrm{P}: \mathrm{C}(55: 45), \mathrm{HF}$ & $14.64^{\mathrm{AB}}$ & $0.171^{\mathrm{B}}$ & $0.010^{\mathrm{A}}$ & $0.025^{\mathrm{B}}$ \\
\hline
\end{tabular}

${ }^{\mathrm{z}}$ values [represent measurements made on 3 replication ( 3 seedlings mixed per replication) per treatment] in columns followed by the same small letter are not significantly different, $\mathrm{p}<0.05$, regarding substrate medium and in columns followed by the same capital letter are not significantly different, $\mathrm{p}<0.05$, regarding the fertigation impacts.

Examining the impacts of fertigation in seedling leaf elemental content, leaf $\mathrm{K}$ content increased in case of $15 \%$ MSWC in combination with fertigation (BF and HF) comparing with the relevant control treatments while increased (45\%) MSWC content did not affect the $\mathrm{K}$ elemental content, as high MSWC content is acting as an alternative source for $\mathrm{K}$, available for plant nutrition. The content of $\mathrm{N}$ reduced in $15 \%$ MSWC with BF comparing with the $45 \%$ MSWC and/or non fertigation while the application of $\mathrm{HF}$ did not add any benefits. Na content increased in $45 \%$ MSWC and/or HF application comparing with the $15 \% \mathrm{MSWC}$ and/or BF application and this is might be due to the high EC value of MSWC material. No differences observed in $\mathrm{P}$ content among seedlings grown in substrates with different MSWC content and/or fertigation enrichment. Thus, considerable nutritive value was marked due to the combination of MSWC addition and fertigation into the substrates, as well as affected soil properties (Carbonell et al., 2011).

Transplants are a more reliable method of ensuring the proper establishment of a range of commercial horticultural crops with great economic value, compared with direct sowing. The production of vegetable seedlings, especial in Mediterranean 
countries having expanded field and greenhouse crops areas, is a highly-competitive business; uniform and rapid seed emergence is essential prerequisites to increase yield, quality, earliness and profits in crops. Use of good crop substrates is therefore critical (Sterrett, 2001). Additionally, improved methods of selective waste collection and compost processing will enable increasingly widespread use of this renewable organic compost, as an alternative to highquality sphagnum peat, which - because they are nonrenewable - are less available and more expensive for growers. Successful trials with MSWC into peat-based media for seedling production of tomato, cucumber, melon, basil, and marigold (Vavrina, 1995; Castillo et al., 2004; Mami and Peyvast, 2010; Tzortzakis et al., 2012b; Chrysargyris et al., 2013) displayed good quality indices.

\section{Conclusion}

MSW compost was found to be an ideal component of mixed-peat substrates for eggplant seedlings, provided that it accounts for less than $30 \%$ of the mixture with combination of fertilizers with more positive effects observed if minerals provided through BF rather than HF. These proportions reduce the negative effects of high $\mathrm{pH}$ and $\mathrm{EC}$ on seedling growth, and provide a seedling comparable to that obtained using standard peat-based mixtures. This is in all probability due to a correct balance between nutrient supply from the MSWC and the physical characteristics of peat, particularly substrate porosity and aeration.

\section{Acknowledgement}

We would like to thank E. Dagianta for the technical support in plant analysis.

\section{References}

Adriano, M.de L., Gutiérrez, F., Dendooven, L., Salvador-Figueroa, M. 2012. Influence of compost and liquid bioferment on the chemical and biological characteristics of soil cultivated with banana (Musa spp. L.). J. Soil Sci. Plant Nutr. 12 (1), 33-43.

Almansouri, M., Kinet, J.M., Lutss, S. 2001. Effect of salt and osmotic stresses on germination in durum wheat (Triticum durum Desf.). Plant Soil. 231, 243-254.

Ashraf, M., Foodlad, M.R. 2005. Pre-sowing seed treatment - A shotgun approach to improve germination, plant growth, and crop yield under saline and non-saline conditions. Adv. Agron. 88, 223-271.

Bugbee, G.J. 1996. Growth of Rhododendron, Rudbeckia and Thuja and the leaching of nitrates as a affected by the $\mathrm{pH}$ of potting media amended with biosolids compost. Compost Sci. Util. 4, 53-59.

Carbonell, G., de Imperial, R.M., Torrijos, M., Delgado, M., Rodriguez, J.A. 2011. Effects of municipal solid waste compost and mineral fertilizer amendments on soil properties and heavy metals distribution in maize plants (Zea mays L.). Chemosphere. 85, 1614-1623.

Castillo, J.E., Herrera, F., López-Bellido, R.J., LópezBellido, F.J., López-Bellido, L., Fernández, E.J. 2004. Municipal solid waste (MSW) compost as a tomato transplant medium. Compost Sci. Util. $12,86-92$.

Chrysargyris, A., Saridakis, C., Tzortzakis, N. 2013. Use of municipal solid waste compost as growing medium component for melon seedlings production. J. Plant Biol. Soil Health, 2, 1-5. 
Davidson, H., Mecklenburg, R., Peterson, C. 1994. Nursery Management: Administration and Culture, third ed. Prentice Hall, Englewood CliVs, NJ.

Do, T.C.V., Scherer, H.W. 2013. Compost as growing media component for salt-sensitive plants. Plant Soil Environ. 59, 214-220.

Farrell, M., Jones, D.L. 2009. Critical evaluation of municipal solid waste composting and potential compost markets. Bioresour. Technol. 100, 43014310 .

Fitzpatrick, G.E., Duke, E.R., Klock-Moore, K.A. 1998. Use of compost products for ornamental crop production: research and grower experiences. Hortscience. 33, 941-944.

Giannakis, G., Kourgialas, N.N., Paranychianakis, N.V., Nikolaidis, N.P., Kalogerakis, N. 2011. Effects of solid waste compost on vegetables growth and metals accumulation. 5th European Bioremediation Conference in Chania, 4- 7.7.

Herrera, F., Castillo, J.E., Chica, A.F., López Bellido, L. 2008. Use of municipal solid waste compost (MSWC) as a growing medium in the nursery production of tomato plants. Bioresource Technol. 99, 287- 296.

Hicklenton, P.R., Rodd, V., Warman, P.R. 2001. The effectiveness and consistency of source-separated municipal solid waste and bark composts as components of container growing media. Sci. Hortic. 91, 349-363.

Katayama, A., Ker, K.C., Hiraj, M., Shoda, M., Kubota, H. 2012. Stabilization process of sewage sludge compost in soil. Soil Sci. Plant Nutr. 33, 123-135.
Kattimani, K.N., Reddy, Y.N., Rao, R.B. 1999. Effect of presoaking seed treatment on germination, seedling emergence, seedling vigour and root yield of Ashwagandha (Withania somnifera Daunal.). Seed Sci. Technol. 27, 483-488.

Kelepesi, S., Tzortzakis, N.G. 2009. Olive-mill wastes - A growing medium component for seedling and crop production of lettuce and chicory. Int. J. Veg. Sci. 15, 325-339.

Labouriau, L.G. 1983. Seed germination. Organization of American, Washington. 174 pp.

Mami, Y., Peyvast, G. 2010. Substitution of municipal solid waste compost for peat in cucumber transplant production. J. Hort. Forestry. 2, 157160.

McConnell, D.B., Shiralipour, A., Smith, W. 1993. Compost application improves soil properties. Biocycle. 34, 61-63.

Murillo-Amador, B., Lopez-Aguilar, R., Kaya, C., Larrinaga-Mayoral, J., Flores-Hernandez, A. 2002. Comparative effects of $\mathrm{NaCl}$ and polyethylene glycol on germination, emergence and seedling growth of cowpea. J. Agron. Crop Sci. 188, 235-247.

Pal, R., Bhattacharyya, P. 2003. Effect of municipal solid waste compost on seed germination of rice, wheat and cucumber. Arch. Agron. Soil Sci. 49, 407-414.

Pimpini, F., Gianquinto, G. 1991. Primi resultati sulle modalita di allevamento invivaio di piantina di pomodoro da industria. Riflessi su aecrescimento e produzione in campo. 2 Convego Nazionale "Il vivaismo Octicolo". Foggia.

Porra, R.J. 2002. The chequered history of the development and use of simultaneous equations for the accurate determination of chlorophylls $a$ and $b$. Photosynthesis Res. 73, 149 - 156. 
Ribeiro, H.M., Romero, A.M., Pereira, H., Borges, P., Cabral, F., Vasconcelos, E. 2007. Evaluation of a compost obtained from forestry wastes and solid phase of pig slurry as a substrate for seedlings production. Bioresource Technol. 98, 3294-3297.

Ribeiro, H.M.F., e Santos, J.Q. 1997. Utiliçao de residuos sólidos urbanos comportados na formulaçao de sustratos: Efeito nas propiedades físicas e químicas dos sustrato. Actas de Horticultura. Vol. 18-II. Cong- reso Iberoamericano e III Congreso Ibérico de Ciencias Hortícolas. 11-15 Março, 1997, Vilamoura, Portugal.

Sanchez-Monedero, M.A., Roig, A., Cegarra, J., Bernal, M.P., Noguera, P., Abad, M., Anton, A. 2004. Composts as media constituents for vegetable transplant production. Compost Sci. Util. 12, 161-168.

Sterrett, S.B. 2001. Compost as horticultural substrates for vegetable transplant production. In: Stoffella, P.J., B.A. Kahn (Eds.), Compost Utilization in Horticultural Cropping Systems. Lewis Publication, Boca Raton, FL, pp. 227-240.

Taheri, N., Sharif-Abad, H.H., Yousefi, K., RohollaMousavi S. 2012. Effect of compost and animal manure with phosphorus and zinc fertilizer on yield of seed potatoes. J. Soil Sci. Plant Nutr. 12 (4), 705-714.

Tzortzakis, N., Gouma, S., Dagianta, E., Saridakis, C., Papamichalaki, M., Goumas, D., Manios, T. 2012a. Use of fertigation and municipal solid waste compost for greenhouse pepper cultivation. TheScientificWorldJOURNAL, vol. 2012, Article ID 973193, pp. 1-8.
Tzortzakis, N., Gouma, S., Paterakis, C., Manios, T. 2012b. Deployment of municipal solid wastes as a substitute growing medium component in marigold and basil seedlings production. TheScientificWorldJOURNAL, vol. 2012, Article ID 285874, pp. 1-6.

Vavrina, C. 1995. Municipal solid waste materials as soilless media for tomato transplant. Proceedings of the Florida State Horticultural Society 108, $232-234$.

Verma S.L., Marschner, P. 2013. Compost effects on microbial biomass and soil $\mathrm{P}$ pools as affected by particle size and soil properties. J. Soil Sci. Plant Nutr. 13 (2), 313-328.

Zaccardelli, M., De Nicola, F., Villecco, D., Scotti, R. 2013. The development and suppressive activity of soil microbial communities under compost amendment. J. Soil Sci. Plant Nutr. 13(3), 730742 .

Zhang, J., Maun, M.A. 1990. Seed size variation and its effects on seedling growth in Agropyron psammophilum. Botl. Gaz. 151, 106-113.

Zucconi, F., Pera, A., Forte, M., DeBertolli, M. 1981. Evaluating toxicity of immature compost. Biocycle. 22, 54-57. 